\title{
The role of risk in the context of climate change, land use choices and crop production: evidence from Zambia
}

\author{
Alessandro De Pinto ${ }^{1, *}$, Vincent H. Smith ${ }^{2}$, Richard D. Robertson ${ }^{1}$ \\ ${ }^{1}$ Environment and Production Technology Division, International Food Policy Research Institute, 1201 Eye Street, NW, \\ Washington, DC 20005, USA \\ ${ }^{2}$ Department of Agricultural Economics and Economics, Montana State University, PO Box 172920, Bozeman, MT 59717, USA
}

\begin{abstract}
Most of the studies that investigate the impacts of climate change on agriculture have concentrated on the effects of changes in mean temperature and precipitation even though the importance of volatility and risk on farmers' decision making is well documented. This study examines the empirical importance of the effects of risk associated with the impacts of climate change on farm land allocations and consequent effects on agricultural output in Zambia. We used a discrete-choice model consistent with a mean-variance utility function to model farm-level land allocations among alternative crops. Results indicate that risk-reducing decisions can reinforce crop shifts driven by climate change impacts on mean temperature and precipitation. While an analysis of the available per-capita daily nutrients reveals that farmers' crop allocation choices can mitigate the negative effects of climate change, the opportunity cost of these decisions is explored through a simulation scenario in which yield variability is reduced to zero. Reduction of yield variability leads to land allocations that result in a sizable increase in total crop production and a significant increase in available per capita daily calories. Important conclusions can be derived from this analysis. First, the risk environment matters and should not be ignored. When the economic effects of climate change are considered, decision making under uncertainty and risk should be at the forefront of the problems that need to be addressed. Second, concentrating on farm-level effects of responses to climate change is not sufficient. To understand the economy-wide consequences of climate change, the aggregate effects of individual decisions should be assessed. Third, results indicate that increased efforts in risk management and in developing policies aimed at reducing risk can lead to significant positive outcomes for the nutritional status of low-income, food-insecure populations.
\end{abstract}

KEY WORDS: Climate Change $\cdot$ Risk and volatility $\cdot$ Farmland crop allocation $\cdot$ Land use change

\section{INTRODUCTION}

Climate change is a significant and growing threat to the world's food supply and food security. It has already directly affected vulnerable populations in many developing countries and is expected to affect many more people in the future, even if the implementation of remedial actions began today (IPCC 2018). Importantly, the worst-hit areas are (and will continue to be) the underdeveloped economic regions

*Corresponding author: a.depinto@cgiar.org of the world, where food security is already problematic and populations are highly vulnerable to the effects of climatic and other shocks (Krishnamurthy et al. 2014, Richardson et al. 2018). The poorest households will likely be disproportionally affected because of their dependence on agriculture and lower capacity to adapt to changing conditions (World Bank 2010, Rosegrant et al. 2014). Farmers in many agricultural regions already appear to have experienced declines in crop production because of climate change-

(C) The authors 2019. Open Access under Creative Commons by Attribution Licence. Use, distribution and reproduction are unrestricted. Authors and original publication must be credited. 
induced stress (Lobell \& Gourdji 2012, Mora et al. 2015). While climate change is expected to produce both winners and losers, the loss of productivity in many regions is expected to outweigh gains in other regions (Jarvis et al. 2011, Wiebe et al. 2015).

Until now, the effects of changes in mean temperature and precipitation have been the main focus of discussions about climate change impacts on agriculture and the quantitative modeling of those impacts. However, other analyses (Lobell et al. 2011, Pugh et al. 2016) suggest that these impacts will include shifts in the timing of optimal planting and harvesting periods, increased variability in growing conditions, and greater uncertainty in predicting short-term weather events like the onset of rainy and dry seasons, complicating smallholder farmers' production decisions. Furthermore, the IPCC has repeatedly indicated that increases in the frequency of droughts are fairly likely (IPCC 2012, 2014).

Generally, when estimating the effects of climate change on agricultural production, food prices, and the wellbeing of the poorest households in developing (and other) countries, economists and other modelers have focused on the impacts of average climate change effects (e.g. changes in average temperatures and average rainfall). The effects of climate change on the volatility of agricultural production, crop and livestock prices, and longer-term producer responses to the associated increased risks have received much less attention.

Economists have long been aware of the potential importance and role of risk in farmers' decision making. Baron (1970), for example, argued that a riskaverse firm's output will be less than optimal. Sandmo (1971) showed that, under price uncertainty, a risk-averse firm's optimal output is lower than under price certainty. However, Finkelshtain \& Chalfant (1991) noted that when agricultural households face multivariate risk, both as consumers and producers, as is typical for many smallholder farm households in developing countries, Sandmo's result is a special case, and farm output differs from what it would be when prices are known with certainty.

Empirically, 2 types of studies have examined evidence on risk attitudes. One approach has been to use econometric models to identify effects of risk attitudes on farm household production decisions and, by implication and through an indirect approach, to test whether farm behaviors are consistent with the assumption that farmers on average are risk-averse (e.g. Just \& Pope 1978, Saha 1993, Chavas \& Holt 1996). The other approach has used experimental economics techniques to identify risk preferences directly, typi- cally through an array of carefully constructed lotteries in generic or stated-choice contexts (Harrison et al. 2010, Tanaka et al. 2010, Marenya et al. 2014, Tanaka \& Munro 2014). In empirical climate change studies, however, in-practice risk-neutrality is generally assumed, even though the economic literature has emphasized the potential effects of price and yield volatility on farmers' production decisions.

This paper explores the importance of accounting for risk when farmland crop allocations, agricultural production and, more generally, food security are evaluated in the context of climate change. The empirical question that motivated this paper was whether or not modeling farmers' responses to climate change requires accounting for their risk attitudes. Is risk only a second-order effect of negligible importance or, alternatively, does accounting for risk in empirical models result in quantitatively and statistically significantly different results about the effects of climate change on agricultural production and food systems? The results of this study indicate that the aggregate effect of farmers' actions, driven in part by yield and price volatility and compounded by changes in crop-growing conditions caused by climate change, may adversely affect overall production and nutrient availability at the country level. Disregarding the influence of risk in farmers' responses can lead to the formulation of poorly targeted polices and can insidiously affect a country's production of food. These findings also highlight the potential importance of innovations that mitigate the risks caused by climate change (e.g. investments in developing drought-tolerant crop varieties, irrigation systems, etc.) and providing farmers with access to efficient risk management tools.

\section{DATA AND METHODS}

\subsection{Agriculture and nutrition in Zambia}

While not among the African economies expected to suffer the worst consequences of climate change, Zambia is a country still heavily dependent on agriculture whose economic growth could be stifled by changing climate regimes and a higher incidence of extreme weather events. Thus, it is representative of many emerging economies around the world for which climate-proofing investments are needed, along with the development of policies that effectively address climate change risks. Agriculture is a major component of the Zambian economy, currently involving over $60 \%$ of Zambia's labor force (FAO 
2016a). Analyses of peoples' sources of food and income show that the livelihood of most rural households is highly dependent on agriculture (Fig. 1) (FEWS NET 2014). The vast majority of farmers cultivate small plots, typically less than 5 ha, using only basic inputs and technologies (Jain 2007).

Maize, cassava, groundnut, millet, sorghum, and cotton are the most commonly grown crops. Maize is the largest source of calorie consumption, the staple food for $82 \%$ of Zambian smallholder households, and a principal source of food security (Dorosh et al. 2009, FAO 2016a), with production concentrated in Zambia's Eastern, Central and Southern Provinces (Sitko et al. 2011). Cassava, the second most important food crop in the country, is mainly grown in Zambia's Northern Province (Aregheore 2009). About 23\% of the per capita supply of protein comes from animal products (Aregheore 2009), although in some provinces such as Laupula and the Northern Province, fish is the largest source of protein (Aloafe et al. 2014). Groundnuts are a significant source of plant-based protein (Sitko et al. 2011), while cassava provides protein, minerals, and vitamins (Sitko et al. 2011). Roots, tubers, beans, nuts, grains, and fish products are the main sources of vitamins and micronutrients (Aloafe et al. 2014). Only the urban populations in Lusaka, Kitwe, and Mans spend significant amounts of their incomes on fruits, vegetables, and animal protein, including dairy products (Mwala \& Gisselquist 2012).

Historically, government programs have included subsidies on inputs, fertilizer, and seed credits, as well as subsidizing transport costs in remote areas and farmer debt forgiveness programs. In the 1970s and 1980s, those programs were largely targeted towards maize, resulting in a substantial increase in production and area planted (Jayne et al. 2007). In the early 1990s, however, in response to budgetary pressures, the Zambian government implemented major structural adjustments to government programs and introduced agricultural market reforms (Seshamani 1998, Govereh et al. 2006, Mason et al. 2013). Maize marketing and input subsidies were eliminated, and agricultural markets and trade were liberalized. In response, maize production declined, especially in Northern Zambia, and farmers reallocated land towards food crops like cassava, groundnuts, and sweet potatoes, and turned to cotton as a cash crop (Siegel \& Alwang 2005, Jayne et al. 2007, Zulu et al. 2007). Between 1990-1991 and 20022003, maize's share of total smallholder crop output declined from 76-55\% (Jayne et al. 2007) while cassava's share increased from 10-26\% (Govereh et al. 2008). Cassava is currently the second largest source of calorie consumption in Zambia (Dorosh et al. 2009). Cotton production increased in part because of private sector investments. In 2003-2004, 1 out of every 5 small farms planted cotton (Govereh et al. 2006) and between 2008 and 2012, cotton production almost doubled (Chapoto et al. 2012).

\subsection{A model of land-use choices}

Economists often estimate multi-crop econometric models derived under the assumption of profit maximization with land as an allocable fixed input to


Fig. 1. Zambian livelihood zones in 2014. Source: FEWS NET (2014) 
explain land use decisions by farmers (Chambers \& Just 1989, Moore \& Negri 1992, Oude Lansink \& Peerlings 1996, Fezzi \& Bateman 2011). An alternative approach is to model land allocation decisions using a discrete-choice setting because it leads to conveniently tractable, empirically relevant model specifications (Wu \& Segerson 1995, Miller \& Plantinga 1999, Livingston et al. 2008). More recently, Carpentier \& Letort (2014) showed that, under reasonable assumptions, discrete-choice models (and specifically, multinomial logit models) can be interpreted as solutions to a farm's land-use optimization problem based on profit maximization. However, as Carpentier \& Letort (2014, p. 541) state: 'the [multinomial logit] framework imposes non-jointness restrictions of the multicrop technology in variable inputs, in outputs and in acreages.' A direct consequence of these restrictions is that the non-jointness of the quasi-fixed input requirements with respect to variable input uses can only hold in the neighborhood of the current level of input usage. Thus, the multinomial logit model framework cannot be used to make long-term projections regarding crop allocation shares. As such, our objective was not to make precise predictions about future land-use patterns in Zambia, but rather to gain insights into the possible importance of risk in farmers' crop allocation decisions when they are exposed to climate change. That provides an insight into how current farmers, as portrayed by available surveys, would respond when exposed to climate change. In this formulation, farmers are assumed to be constrained by a fixed amount of land, their current levels of human and social capital, and the technologies currently available to them. In reality, the passage of time provides farmers with flexibility in the use of all factors of production. This flexibility could accentuate or moderate land reallocations across crops that occur in the short term. Even with these limitations, a discrete-choice model can show that, when dealing with climate change, risk should not be viewed as a second-order effect that can be ignored because it is overpowered by the long-term effect of changes in temperature and precipitation means.

To shed light on this issue, we followed an approach that stands at the intersection of the work of Chavas \& Holt (1990) and Wu \& Segerson (1995). Specifically, we modified Wu \& Segerson's (1995) model to include farmers' risk attitudes, which can affect their land allocation choices. The household, which is assumed to be a price-taker, maximizes expected utility derived from farming available land holdings by allocating area $a_{j}$ to each available crop $j$ :

$$
\max _{a_{j}}\{E U[\Pi, \Omega, C, \mid W, A]\}
$$

where $E$ is the expected value, $U$ is a utility function describing the impacts on the decision maker's utility of the level of profits $(\Pi)$, and their volatility $(\Omega)$, and their prodcution costs $(C)$ conditioned on wealth $(W)$, including land endowments $(A)$. This implies that there is an optimal area allocation function $F$, where $a_{j}^{*}=F[\Pi, \Omega, C, W, A]$ to each crop that solves the farmer's utility maximization problem. Through the use of a set of assumptions about functional form and the distribution of the unobserved components of the utility function (details provided in Text S1 in the Supplement at www.int-res.com/articles/suppl/c079 p039_supp.pdf), we can reformulate the household's problem in terms of crop shares (the fraction of farm land allocated to each of the 1 to $J$ crops, $s_{j}$ ) and express the maximization problem as follows:

$$
s_{j}^{*}=\frac{\exp \left[s\left(\Pi_{j}, \Omega_{j}, C, W, A\right)\right]}{\sum_{i=1}^{J} \exp \left[s\left(\Pi_{j}, \Omega_{j}, C, W, A\right)\right]}
$$

We estimated 2 model types: a standard multinomial logit model and a 2-level nested multinomial logit model (see Fig. 2). In both models, the probability of a crop being chosen is interpreted as the share of the available land to be allocated to the crop (Theil 1969, Berry 1994, Greene 2003). Nested multinomial logit models are estimated sequentially under assumptions analogous to the multinomial logit model, but with the error terms for crop shares correlated within each nest and uncorrelated among nests.

\subsection{The data}

The data used to estimate the land-use models were obtained from multiple sources. These include nationwide survey information on individual farm households that identified the district in which the households were located, simulation-based, district-level information on crop yields, transportation costs, and weather data, and province-level information on crop prices. Cross-section data on farm practices and household characteristics of a country-wide stratified sample of 5319 smallholder farmers were obtained from the 2004 Zambia Rural Income and Livelihoods Survey (Central Statistical Office 2012). The survey, which sampled households from 72 districts, is representative at the provincial level and, together with farm and household characteristics (see Table 1), provides information on land allocations and cropspecific revenues for the 2003-2004 crop year. A total 
of 6 crops were selected to be modeled based on their importance and the data available in the survey: maize, millet, sorghum, cassava, groundnuts, and beans. These crops occupy $63 \%$ of all land allocations reported in the survey. The land allocated to all other crops, including land in fallow, were grouped in a category called 'others'. Land reported as fallow accounted for approximately $58 \%$ of the 'others' category.

\subsubsection{Household data}

The number of household members and the reported value of agricultural assets (i.e. the value of farming tools and machinery present on the farm) was used to control for the implicit management cost of allocation choices and binding constraints on potential allocations derived from limiting quantities of quasi-fixed inputs. As proxies for household wealth, we used 2 variables: the number of livestock owned and the declared off-farm revenues reported by the household. The size of the land farmed by each household was reported in the household survey.

\subsubsection{Revenues, costs, yields, and volatility}

The 2004 Zambia Rural Income and Livelihoods Survey reported crop yields and crop-specific revenues but did not provide information on cropspecific production costs. To account for their effects on land allocation choices, we used the cost of offfarm labor for one day's work, the unit cost of fertilizers reported in the survey, and we accounted for transportation costs by including a cost-of-access measure based on time to the nearest city of 20000 people (Nelson 2008). Given that we could only identify the district in which each farm was located, the median value of the cost-of-access measure was used for each district. To account for variability within the district, we included the inter-quartile spreads to capture the heterogeneity of this measure at this level of geographical disaggregation.

Other factors can constrain a household's crop allocation choices by limiting the time in which field activities can be carried out (e.g. field operations like sowing, harvesting, processing). While these management costs were not recorded in the household survey, we controlled for them by including the values of median temperature and precipitation in the set of explanatory variables, given that these 2 variables affect the timing and cost of field operations. The weather data used to construct these variables consisted of historical climate information reconstructed by the National Centers for Environmental Prediction (NCEP) model covering the years 19502010 (Kalnay et al. 1996). The daily precipitation values were refined to match the data gathered by the Global Precipitation Climatology Centre project at the monthly level, since they are believed to be more reliable (Rudolf et al. 1994, 2003, Back et al. 2005, Rudolf \& Schneider 2005, Schneider et al. 2011, 2014). Diversity within the district was proxied by computing the inter-quartile range of values. Furthermore, given the relatively rigid roles that men and women play in agriculture in Zambia, we accounted for the gender of the head of household, which, with their differing knowledge bases and abilities, can have an effect of the costs of production for particular crops.

Time-series data on crop prices for maize, millet, cassava, beans, sorghum, and groundnuts at the province level for the period 1994-2012 (Central Statistical Office 2014) were used to compute alternative estimates of price volatility for each crop. The assumption was that, even though some prices included in the estimates of standard deviations were observed after the cross-sectional household sample was collected in 2004, the volatility reflected in those prices reflects the crop-price data-generating process extant in 2004. While alternative land-use models were estimated using several different measures of price volatility, results are reported only for models that used simple 'raw' estimates of crop price standard deviations computed using nominal prices and standard deviation estimates based on de-trended prices. The signs of the parameter estimates did not vary across alternative measures of price volatility, but models utilizing simple standard deviations as measures of price volatility were consistently preferred when log-likelihood values were compared across models.

Yield distributions for each crop were generated using the Decision Support System for Agrotechnology Transfer (DSSAT; Jones et al. 2003). Crop yields were obtained using historical daily weather in DSSAT. The approach we followed was to combine information on weather variables and soil type at the district level to generate yield distributions for each crop using the DSSAT crop model. Specifically, we directly modeled the following crops under rainfed conditions: beans, cassava, groundnuts, maize, millet, and sorghum. Daily weather observations were available at a geographic resolution of $0.5^{\circ}$, and consisted of 46 yr drawn from the second half of the $20^{\text {th }}$ century and the early portion of the current century. 
The size of the half-arc-degree grid-cell varied with latitude. For locations close to the equator such as Zambia, this corresponds to a square of approximately $50 \times 50 \mathrm{~km}$. At each location in Zambia, the growth of each crop was simulated with the daily weather of each of the $46 \mathrm{yr}$ and with 3 different planting months (October, November, and December). The choice of planting month was based on which one returned the highest average yield over the 46 yr period. Yearly yields generated in this way were used for computation of the crop-specific yield variability measures. Each crop experiences the same weather in the same years, so the yields generated for each crop can be directly compared. This is important from a risk perspective because a lowyielding crop could be more valuable than its mean yield implies if it does comparatively well in years when higher yielding crops do poorly. Since more than one DSSAT grid cell is present in each district, an average value for each district was used. Additionally, the inter-quartile spreads within the districts were computed to provide an indication of how much heterogeneity is present. The same procedures were then used to generate estimates for yield changes and yield volatilities under the climate conditions projected for 2050.

\subsubsection{Yields, precipitation, and temperature under future climate conditions}

Yields, yield variability, and future precipitation and temperature (in the middle of the century) were obtained by applying climate change patterns extracted from MIROCESM-CHEM under RCP8.5 (Watanabe et al. 2011) to the historical daily weather. Raw climate change data were obtained from the Potsdam Climate Institute (PIK). In those data, the daily raw general circulation model (GCM) outputs were spatially resampled to a $0.5^{\circ}$ grid and then de-biased to match appropriate historical benchmarks (Piani et al. 2010, Weedon et al. 2011, Hempel et al. 2013, Müller \& Robertson 2014). Those daily timeseries data were aggregated to monthly averages over 3-decade periods to provide a baseline/historical set of monthly averages (1981-2010; centered on 1995-1996) and a future case (2041-2070; centered on 20552056). The changes between those periods were extracted and then applied to the daily weather as additive shifts for temperatures and scaling for precipitation and shortwave solar radiation. The result is a set of future daily weather realizations that are exactly analogous to baseline weather, but embody the climate anticipated by the GCM. Note that this is still more-or-less a mean shift effect and that variability in weather (both dayto-day and year-to-year) is based on historical patterns; therefore, future weather outcomes are based on the historical variability of temperature and rainfall but in the context of average levels that account for the changed climate. For this study, we used climate change data from MIROC-ESM-CHEM under RCP8.5. These daily weather realizations were used in DSSAT following the same method described earlier to derive yield changes due to the changing climate as well as yield variability. The differences in the DSSAT-simulated yields for the years 2004 and 2050 were then applied to the yields recorded in the survey to calculated crop yields in 2050. A complete list of variables and variable definitions together with data on sample means, ranges, and (where relevant) standard deviations for each variable is presented in Table 1.

Table 1. Variable sample means, ranges and other descriptive statistics related to Zambian smallholder farmer land allocation and cropspecific revenues for 2003-2004. Kwacha: currency of Zambia

\begin{tabular}{|c|c|c|}
\hline Variable & Mean & $\mathrm{SD}$ \\
\hline Precipitation $(\mathrm{mm})$ & 1042.83 & 274.52 \\
\hline Precipitation inner quartile range $(\mathrm{mm})$ & 14.93 & 17.48 \\
\hline Temperature $\left({ }^{\circ} \mathrm{C}\right)$ & 178.80 & 21.71 \\
\hline Temperature inter-quartile range $\left({ }^{\circ} \mathrm{C}\right)$ & 16.66 & 12.71 \\
\hline Cost of access (ln[travel time in minutes]) & 5.90 & 0.51 \\
\hline $\begin{array}{l}\text { Cost of access inter-quartile range } \\
(\ln [\text { travel time in min]) }\end{array}$ & 1.03 & 0.27 \\
\hline Revenue maize (kwacha ha ${ }^{-1}$ ) & 318624.0 & 15509.20 \\
\hline Revenue millet (kwacha ha ${ }^{-1}$ ) & 279297.5 & 27552.66 \\
\hline Revenue sorghum (kwacha ha ${ }^{-1}$ ) & 180277.2 & 11029.49 \\
\hline Revenue cassava (kwacha ha ${ }^{-1}$ ) & 139837.9 & 77470.27 \\
\hline Revenue groundnuts(kwacha ha $\left.{ }^{-1}\right)$ & 736941.5 & 26579.24 \\
\hline Revenue beans (kwacha ha ${ }^{-1}$ ) & 509114.6 & 11868.22 \\
\hline Maize net-revenue variability & 77.81 & 10.29 \\
\hline Millet net-revenue variability & 29.84 & 14.27 \\
\hline Sorghum net-revenue variability & 24.38 & 13.88 \\
\hline Cassava net-revenue variability & 17.79 & 9.44 \\
\hline Groundnuts net-revenue variability & 97.86 & 67.37 \\
\hline Beans net-revenue variability & 82.72 & 55.84 \\
\hline Off-farm cost of labor (kwacha d $\mathrm{d}^{-1}$ ) & 40.59 & 8.14 \\
\hline Fertilizers price (kwacha kg-1) & 1859.52 & 214.24 \\
\hline Farm size (ha) & 2.37 & 2.80 \\
\hline $\begin{array}{l}\text { Gender head of household } \\
\text { (dummy variable; } 1=\text { female) }\end{array}$ & 0.22 & 0.42 \\
\hline Number of household members & 6.10 & 3.20 \\
\hline Value of assets (kwacha) & 381196.67 & 3751218.50 \\
\hline Number of head of livestock & 2.52 & 13.88 \\
\hline Off-farm revenues (kwacha) & 1433.79 & 17.96 \\
\hline
\end{tabular}




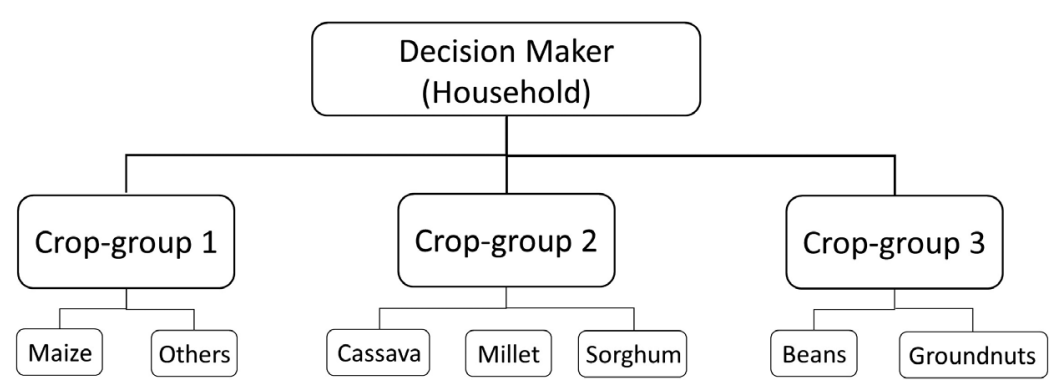

Fig. 2. Structure of the nested multinomial logit model

but omits temperature and rainfall, 2 of the explanatory variables that attempt to control for the field operation costs that are affected by weather conditions.

Log-likelihood ratio tests indicated that that a nested logit model that includes the risk-related variables and the variables to control for costs of production is preferred over the others. In all nested logit models, other variables generally have the same signs. One difference is that in the model that in-

\section{RESULTS}

\subsection{Estimation results}

We estimated several alternative discrete-choice land-use models. Parameter estimates are reported in Tables S1 \& S2 in the Supplement for 4 models that are representative of the results we obtained ${ }^{\mathbf{1}}$. The first is a multinomial logit model which uses all the variables present in the nested logit model, including the variables that account for the variability of crop revenues. The second is a nested logit model (as described in Fig. 2) that relaxes across nests the independence of irrelevant alternatives (IIA) assumption implicit in the multinomial logit specification. Likelihood ratio tests indicated that a nested logit model is preferred to a multinomial model. The third and fourth empirical models were estimated to examine whether the inclusion of a range of explanatory variables is warranted. Model 3 is a nested logit model that excludes explanatory variables that account for risk but otherwise has an identical set of explanatory variables. Finally, model 4 is also a nested logit model

\footnotetext{
1. It is possible that spatial effects are present at multiple levels: district to district, province to province, village to village, household to household. And it is also possible that some omitted variables cause spatial correlation in the error terms. We do not have sufficient data to fully control for these effects, although our estimated model includes a series of explanatory variables that should account for the direct influence that the surrounding environment might have on land-use decisions made in a particular location (e.g. inter-quintile ranges for distance and elevation). One alternative model specification we tested included 2 additional explanatory variables representing latitude and longitude of the district where the observation is located. This type of correction is likely to be helpful when the spatial effect is caused by an unobserved variable that varies linearly over the area. While the inclusion of these variables changed the value of parameter estimates, it did not change the signs of any of the other parameters and did not meaningfully affect the overall results.
} cludes the risk-related variables, more of the parameter estimates for crop revenue variables are statistically significant, while generally retaining the same expected positive signs.

The signs of the estimated parameters corresponding to the risk-related variables included in both the nested logit and the multinomial logit model were as expected (that is, negative, which indicates that all things being equal, an increase in volatility decreases the attractiveness of that crop or nest being chosen) with one exception (the risk-related variable for maize in the nested logit without the weather variables). In the nested logit model, the estimated riskrelated variable parameters were also statistically significant for all crops except maize and cassava.

The results also indicate that including farm size as a determinant of land allocation in crop share models may be important. The parameter estimates for farm size in the nested logit model suggest that as farm size increases, a greater share of available farm land is allocated to group-1 crops (a group that includes maize and the 'others' category). The nested logit model, however, cannot indicate whether within that group a larger share of land is being allocated to both maize and the 'others' category or only 1 of the 2 land uses. The parameter estimates for farm size in the multinomial logit suggest the increased share of land allocated to group-1 crops will be concentrated on the 'others' crops. All farm size parameter estimates were negative, indicating that all crops become less attractive than reference category crops ('others') as farm area increases. It is useful to remember that the 'others' category includes 2 cash crops, sugarcane and cotton, along with fallow - which suggests that at the farm householder level, larger land holdings may lead to an increase in crop diversification and act as a form of risk management.

Households headed by women tend to allocate less land to group-2 crops, which include cassava, millet, and sorghum, and more land to group-1 crops (maize 
and 'others') and group-3 crops (beans and groundnuts), which are protein crops. This result is consistent with anecdotal evidence, also observed in the field by the authors that, traditionally and culturally, men favor the production of maize while women allocate the land they control to vegetables and legumes. The labor cost variable also has a similar effect; higher off-farm wages reduce the amount of land allocated to group- 2 crops. Parameter estimates also suggest that higher fertilizer prices reduce the amount of land allocated to group-1 crops (which include maize) and increase the amount of land allocated to crops in the other 2 groups. The results also indicate that as average rainfall increases and the inter-quartile range for rainfall increases, land is reallocated from the 'others' category to maize, millet, cassava, sorghum, groundnuts, and beans. As average temperatures and the inter-quartile of temperatures increase, land is reallocated to the 'others' category from maize, millet, cassava, sorghum, groundnuts, and beans.

Households with more assets and a higher number of household members are likely to allocate less land to group-2 crops and more land to group-1 and -3 crops. According to our parameter estimates, an increase in off-farm revenue increases the share of land allocated to crops in groups 1 and 2 .

\subsection{Simulation results}

\subsubsection{Effects of temperature and precipitation} vs. volatility

The nested logit model permits an evaluation of the relative importance of changing mean temperatures and precipitation values vis-a-vis the effects of changing revenue volatility. To examine this issue, we used a comparative statics approach with projections from 2 alternative simulations. The first simulation examines changes in land allocations in response to the temperatures and precipitation expected in 2050 and their effects on crop revenues-holding revenue volatility constant at 2004 levels. The second simulation projects changes in land allocations when, given the impacts of climate change on yield volatility, the revenue volatility expected in 2050 is used-keeping rainfall, temperature, and yields constant at 2004 levels.

Fig. 3 shows the projected average land allocations using the 2 different modeling settings and the projected average changes with respect to the allocations recorded in the survey in 2004 . While the effect

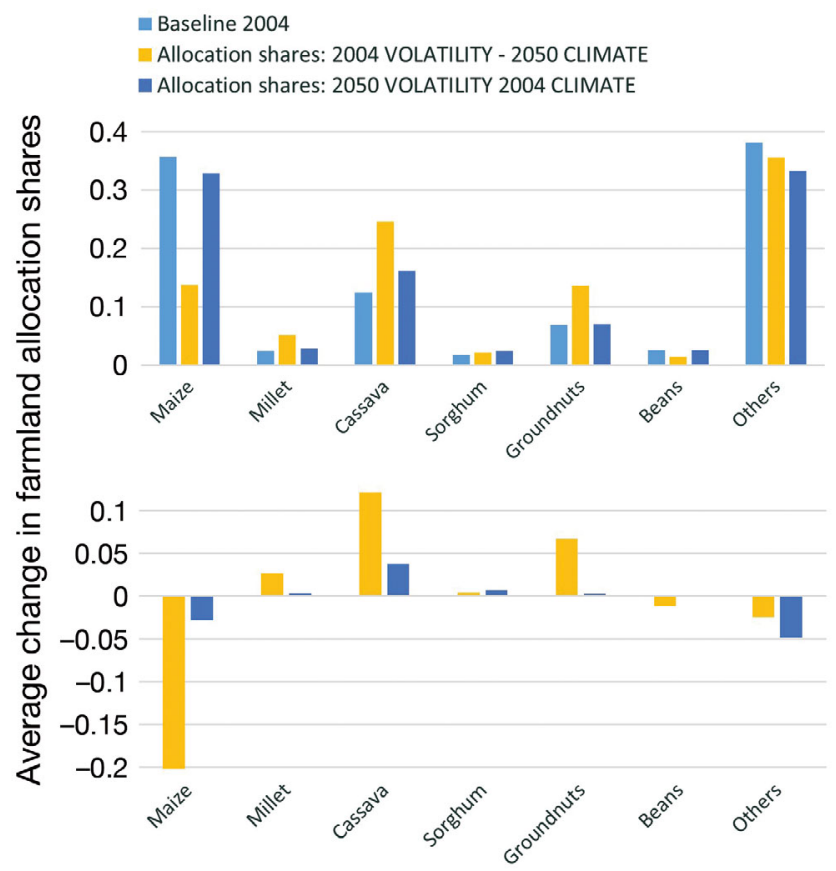

Fig. 3. Farm land allocations in response to changing temperatures and precipitation vs. changing revenue volatility in Zambia

of changing revenue volatility generally appears to be smaller than the effect of changing temperature and precipitation, it does not appear to be negligible. For example, the change in the share of farm land allocated to maize caused by the change in yield volatility is about $12 \%$ of the change caused by future mean temperatures and rainfall. For cassava, the change in yield volatility is about $30 \%$ of the impact caused by the change in average climate conditions. Furthermore - and this is particularly important for maize and cassava but true for all crops - temperature- and rainfall-induced and risk-induced changes appear to have the same sign and therefore compound their overall effect.

\subsubsection{Effects of climate change on farm land allocations and country production}

The same comparative statics approach can be used to simulate the cumulative, country-level effects of climate change on land allocations by aggregating the decisions made at the farm level in response to changes in temperatures, precipitation, yield, and yield variability projected for 2050. Prices and price volatility are fixed at their 2004 levels, implicitly assuming that climate change will not have an appreciable effect on relative crop prices and that future 
price variability remains the same as the one historically recorded. Furthermore, because of the limitation of the nested logit modeling approach, we simulated farm household responses in terms of farm land shares as represented in the 2004 household survey. Thus, the simulation results reported in this study should not be interpreted as a forecast of what farms in Zambia will look like in 2050. These findings, however, are directly relevant to our understanding of the effects of climate-induced changes in yield volatility and the role of risk in relation to those impacts. Table 2 reports annual average temperatures and precipitation in Zambia for the 2 time periods as well as changes in yields and the variability of net revenues for each crop. Growing conditions deteriorate for all crops but lower rainfall and higher temperatures have different impacts on each crop. Thus, different climate change impacts on crop-specific yield distributions result in different relative effects for crop-specific net revenue variability. Net revenues become more variable for maize, millet, groundnuts, and beans but less variable for cassava and sorghum. Yields of all crops decline, except for sorghum, which is projected to experience a $10.6 \%$ increase in yields.

Table 3 provides information on the average change in land allocations at the farm level for households surveyed, caused by the shift to 2050 climate conditions. In the sample, average farm size is approximately 1.5 ha and the projected average changes are relatively small. The most important change appears to be a transition away from maize in favor of all other crops, particularly cassava. For maize, the median change is a reduction of 0.30 ha and for cassava, an increase of 0.29 ha.

The upper and lower quartiles reported in Table 3 give a sense of the variety of land allocation outcomes that result from the diverse local conditions farmers face. Results indicate, for example, that some households increase the amount of land they plant to maize even though the overall area planted to maize declines. Similarly, some farmers reduce the amount of land planted to sorghum and groundnuts even though the overall area planted to groundnuts increases.

To appreciate the regional and country-wide impacts of the relatively small land reallocations that occur at the farm level, those household-level effects must be combined with the biophysical characteristics of the locations where the land use changes are taking place. The cultivation of a given crop seems likely to shift toward areas where growing conditions become more favorable as climate conditions change. These locational shifts in the production of a crop may be important for total country-wide production and are driven by the relative changes in growing conditions vis-a-vis local biophysical characteristics. For example, on average, maize production is pro-




Table 3. Projected farm-area changes caused by changing climatic conditions in Zambia

\begin{tabular}{|lccccccc|}
\hline Crop & Maize & Millet & Sorghum & Cassava & Beans & Groundnuts & Other \\
\hline Median (ha) & -0.30 & 0.09 & 0.00 & 0.29 & 0.00 & 0.07 & -0.01 \\
$\begin{array}{l}\text { Upper/lower quartiles of } \\
\text { predicted changes in planted area }\end{array}$ & $0.64 /-0.82$ & $0.64 / 0.03$ & $0.61 /-0.01$ & $1.62 / 0.06$ & $1.10 /-0.02$ & $12.67 /-0.01$ & $7.64 /-0.15$ \\
\hline
\end{tabular}



Fig. 4. Projected changes in maize shares across districts in Zambia under predicted 2050 weather conditions tions ('2050 yields and full volatility') are displayed. We report dry matter values to be consistent with the crop model's output and reduce the possibility of errors in properly accounting for moisture content. At the national level, deteriorating growing conditions lead to a significant reduction in output of most crops without changes in land allocations. These reductions are exacerbated by farmers' responses in the case of maize (output is reduced by approximately 566 million tonnes [Mt] dry matter) and beans (output de-

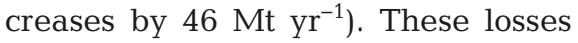
are compensated by increases in the output of sorghum (105 $\left.\mathrm{Mt} \mathrm{yr}^{-1}\right)$, millet (57 $\left.\mathrm{Mt} \mathrm{yr}^{-1}\right)$, cassava (185 $\left.\mathrm{Mt} \mathrm{yr}^{-1}\right)$, and groundnuts (53 Mt $\mathrm{yr}^{-1}$ ) when land use reallocations are simulated. The net effect of land reallocation is a reduction in total dry-matter yearly output of $211 \mathrm{Mt}$ compared to the 2004

jected to decrease in all districts but its proportional decrease is smaller in northern areas. Essentially, maize production appears to migrate toward the north of the country (Fig. 4) where traditionally maize is less common (Fig. 1) but where, according to climate models, precipitation is projected to increase. Note: The values reported are differences from the country mean change in land allocated to maize.

To evaluate climate change impacts on crop production at the country level, recalling that the household survey is statistically significant at the provincial level, we aggregate projected household-level decisions and, for each province, calculate the changes in shares allocated to each crop. Total output effects are computed using the projected provincial shares and DSSAT-derived changes in yields given 2050 climate conditions.

Results are reported in Fig. 5 where baseline production ('baseline-2004 yields'), production under the 2050 climate but no changes in land allocations ('baseline-2050 yields'), and production under the 2050 climate compounded with shifting land alloca- baseline, but an increase of some $114 \mathrm{Mt}$ compared to production if land allocations had not changed.

We obtain insights about the effects of farmers' responses to increased risk by comparing the simulated land allocation using the model that accounts for the volatility in net revenues with the simulated land allocation impacts when yield volatility is reduced to zero leaving price volatility unchanged (displayed in Fig. 5 as '2050 yields; yield volatility reduced'). While this is an admittedly unrealistic scenario, it provides an upper-bound for the effect of reducing yield volatility $^{2}$. Land still transitions away from maize but the transition is mitigated when risk is reduced. In addition, instead of a significant increase in cassava production, cassava production actually declines. Under 2050 climate conditions, reducing net crop

\footnotetext{
${ }^{2}$ Many possible alternative scenarios can be constructed in which volatility (in net revenues, or in prices) can be reduced in total or by a fraction. Some of these were explored but not reported because they do not qualitatively change the results and do not provide additional general insights.
} 




Fig. 5. Comparison of projected future production of crops in Zambia with no land use change and with land use change and full and reduced yield volatility (ignoring moisture)

revenue volatility by setting yield variance to zero leads to an increase in production of millet, sorghum, groundnuts, and beans. In this simulation, land reallocations lead to an increase in annual total dry-matter production, aggregated across all crops, of about $20 \mathrm{Mt}$. These results indicate the potentially important benefits of mitigating the effects of climate change on crop yield distributions. We explored the crop production outcomes under 2050 climate conditions using the model specification that does not account for net revenue volatility. While there are some differences in the magnitude of the projected changes, they are qualitatively similar to the model that reduces yield volatility to zero. This provides an indication of the potentially significant errors that could occur if the risk effects of climate change on land allocation decisions were not taken into account.

\subsubsection{Potential impacts on nutrition}

Our results show that climate-induced changes in temperatures and precipitation have the potential for significant impacts on production. The existing literature already shows how climate change will likely affect several of the dimensions that determine people's food security status, from direct availability of food products to their accessibility (FAO 2016b, Fanzo et al. 2017). Furthermore, new research on the links between nutrition and climate change indicates that some grains and legumes have lower concentrations of zinc and iron when grown under elevated $\mathrm{CO}_{2}$ concentrations (Myers et al. 2014), with poten- tially important adverse impacts on the nutritional status of affected populations. Our simulations indicate that shifts in land-use patterns associated with increased yield and revenue volatility at the farmhousehold level may also have additional effects on the availability of nutrients to smallholders. We explored the potential nutrition effects of changes in the availability of 6 crops included in the analysis by comparing production under 2004 and 2050 climates. To evaluate the nutritional content of the different levels of production, information on nutrient content for maize, millet, sorghum, cassava, beans, and groundnut was collected from the USDA National Nutrient Database (USDA 2015). Using this information, the country-wide total calories, protein, carbohydrates, vitamins, and minerals available in the 6 crops are then computed in each scenario.

Table 4 summarizes the estimates of per capita nutrient availability under the 4 scenarios evaluated in the previous section. The analysis indicates the negative impacts that climate change could have on nutrient and calorie availability. It is only through a reallocation of land across the different crops that the adverse nutrition effects of climate change are mitigated. Per capita daily calorie availability is reduced by $272 \mathrm{kcal}$ without land reallocations and by $226 \mathrm{kcal}$ with land reallocations. Further, the reallocation of land to cassava and groundnut production leads to an increase in the amount of vitamins available. The differences are striking when the scenario with reduced volatility is considered. Notwithstanding the negative effects of climate change on yields, the resulting reallocation of farm land to the different crops leads 


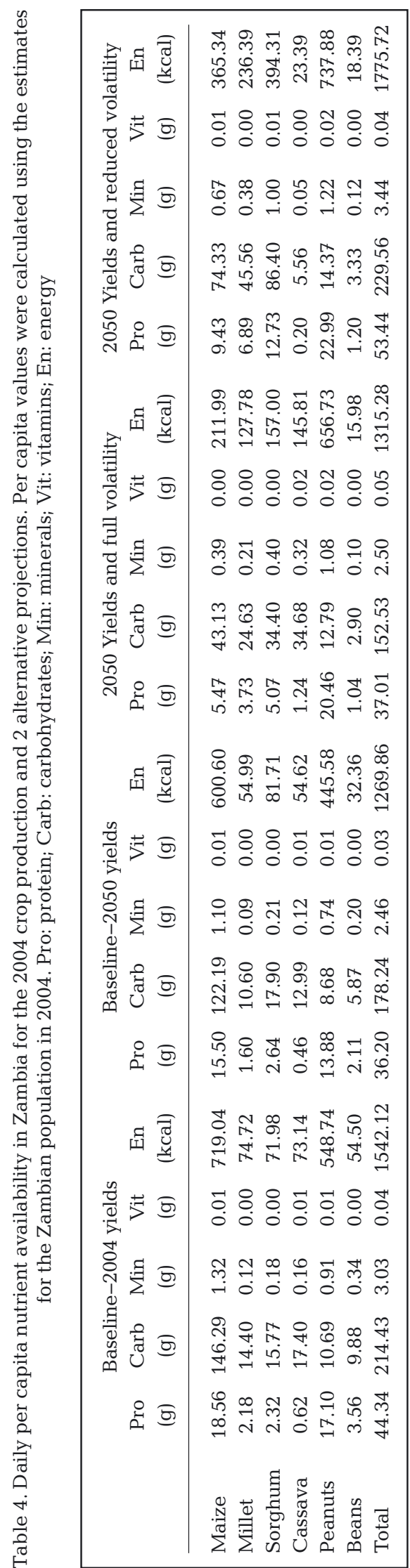

to an increase in daily available calories by more than $233 \mathrm{kcal}$ and an overall increase in the availability of all other nutrients.

Clearly, a population's nutritional status does not depend solely on domestic production. However, evidence suggests that in rural and subsistence conditions, the diversity of diets consumed by infants and young children is directly related to diversity in agricultural production in semi-subsistence households, most specifically for children over the age of 24 mo (Kumar et al. 2015). The evidence presented in this study indicates that, in the context of climate change because of the role of risk in farm production decisions, changes in the volatility of crop revenues also have important and complex effects on the nutrition content of the basket of goods available for consumption in the country. This finding reinforces the importance of including risk in models and analyses, and how instruments that mitigate risk could have important effects not only on production but also on nutrition.

\section{DISCUSSION AND CONCLUSIONS}

Climate change is a significant and growing threat to food security that is already affecting vulnerable populations in many developing countries and is expected to affect more people, more areas, and more farmers in the future. Farmers react to climate change by adjusting their production process in ways that attempt to preserve incomes and consumption. It is well known that price and yield volatility, and more generally risk, matter in farmers' decisions, and many studies have evaluated the effects of risk on decision processes at the farm level. Here, we examined some of the potential effects that climate change may have on farm land allocations by taking into account farmers' risk and risk-avoidance preferences. Further, this study also investigated the aggregated country-wide effects of individual farmers' decisions and the potential implication for total production and nutrient availability under a projected 2050 climate regime.

While the results of this study should not be interpreted as explicit forecasts of what production and land use will look like in Zambia in 2050, they demonstrate that climate change impacts on the risk environment in which farmers operate have substantial and quantitatively important effects on their production decisions. Those risk-related effects on land allocation decisions are in addition to, and compound with, those associated with the impacts of climate change on expected yields, which have been the major focus of most previous studies of climate change impacts on agricultural land use and production. Plans and policies that do not account for risk could potentially fail to include a significant component of the effects of cli- 
mate change, fall short of their objectives, and lead to the inefficient allocation of scarce resources.

The empirical results confirm our expectations about the strategies farmers are likely to adopt to mitigate the additional risks caused by climate change. Farmers shift land from higher-risk crops toward lower-risk crops. In Zambia, this leads to a shift away from maize production towards cassava, millet, sorghum, and groundnuts, whose 'riskiness' appears to decrease relative to maize in the projected 2050 climate regime. From the perspective of a single household, this reallocation of resources is a perfectly rational way of diversifying production to handle the new risks deriving from increased temperature and lower precipitation. This is also reflected in per capita nutrient availability. The negative effects of climate change are mitigated after farm land is reallocated to crops that seem to be more resilient to the degrading growing conditions projected for 2050. From this perspective, land reallocation appears to be a successful strategy.

The findings also indicate that farm size could play a potentially important role in climate changerelated risk management. Larger farms seem to be able to allocate more land to cash crops like sugar cane, cotton, and vegetables and can therefore take advantage of multiple markets. In addition, they can devote more land to fallow, a practice that restores soil fertility and improves soil water retention.

The analysis of the aggregate effects of individual farmers' responses to climate change yields a somewhat different picture. The cumulative country-wide annual output of the crops included in the analysis, measured in dry matter, is estimated to decrease by $211 \mathrm{Mt}$, mainly because of the projected decrease in maize production. To the extent that maize is an export crop, this climate change-induced shift could also have detrimental effects on Zambia's foreign exchange earnings, with possibly larger associated effects on other economic sectors and the country's long-term economic growth potential. It is important to note that the aggregate effects on crop production derive from land reallocations, changes in growing conditions, and the resulting shifts in the location of crop production. In Zambia, for example, maize production shifts toward the north of the country. This result highlights the importance of accounting for the cumulative effects of individual decisions vis-a-vis the spatial characteristics of the location where production takes place. For example, accurate planning of long-term infrastructure investments such as irrigation schemes should therefore account for these interactions.
It is important to note that while the econometric model indicates that risk influences farmers' land allocation decisions, given the estimation procedure, risk-variable parameter estimates show the 'average' effect of changes in that variable for all households. However, the models for which results are reported here do not provide different parameter estimates for farm households that differ by farm size, livelihood, or other characteristics. Thus, the results do not provide insights about differences among farm groups with respect to their quantitative responses to risk. An interesting and important extension to this research would be to investigate whether that effect is consistent across all types of households and regions or if there are differences that can be related to characteristics of individual farms or regions. New surveys, which are now becoming available and contain georeferenced data on households, can therefore substantially improve the analytical capacity of models like the one presented in this study and deserve serious consideration.

The simulations that examine the effects of reducing crop yield volatility also provide insights about the opportunity costs of farmers' choices driven by their riskaverse behavior. The results indicate that there may be substantial overall benefits from innovations in crop varieties that reduce yield volatility and increase crop resilience to adverse, climate change-induced growing conditions. Policies directed to those objectives, such as improved varieties, new agronomic practices and technologies, and effective public investments in irrigation and flood control systems, may also generate substantial social returns.

Farmers' actual responses to climate change are likely to evolve over time as crop growing conditions change incrementally from one year to the next and deteriorate in certain locations and for certain crops. Therefore, policy makers at both the global and country level have the opportunity to develop responses that enable agricultural producers to mitigate these impacts. These responses include facilitating the development and introduction of new production technologies and varieties, and the use of information and communication technologies that provide timely and accurate weather forecasts and input/output price information. All these options require that policy makers be aware and understand the importance of managing the new and exacerbated risks brought about by climate change. This awareness also depends on the capacity of the research community to include the impacts of shifts in the farmer's risk environment in their quantitative assessments of the effects of climate change on agricultural land use and crop production. 
Acknowledgements. This work was supported by the Gender, Climate Change and Nutrition Integration Initiative (GCAN) project with funding from the US Agency for International Development (USAID) and funds from the CGIAR Research Programs on Policies, Institutions, and Market and on Climate Change, Agriculture, and Food Security, which is carried out with support from CGIAR Fund Donors and through bilateral funding agreements. The authors take sole responsibility for the opinions expressed within this report.

\section{LITERATURE CITED}

Aloafe H, Kohler I, Taren D, Mofu MJ, Chileshe J, Kalungwana N (2014) Zambia food consumption and micronutrient status survey report. National Food and Nutrition Commission, Lusaka

Aregheore EM (2009) Zambia country pasture/forage resource profiles. FAO, Rome

Baron DP (1970) Price uncertainty, utility, and industry equilibrium in pure competition. Int Econ Rev 11:463-480

Beck C, Grieser J, Rudolf B (2005) A new monthly precipitation climatology for the global land areas for the period 1951 to 2000. DWD, Klima Statusbericht KSB 2004, p 181-190

Berry S (1994) Estimating discrete choice models of product differentiation. Rand J Econ 25:242-262

Carpentier A, Letort E (2014) Multicrop production models with multinomial logit acreage shares. Environ Resour Econ 59:537-559

Central Statistical Office (2014) www.zamstats.gov.zm/ index.php/publications/category/12-agriculture (accessed 1 September 2019)

Chambers RG, Just RE (1989) Estimating multioutput technologies. Am J Agric Econ 71:980-995

Chapoto A, Haggblade S, Hichaambwa M, Kabwe S, Longabaugh S, Sitko N, Tschirley D (2012) Agricultural transformation in Zambia: alternative institutional models for accelerating agricultural productivity growth and commercialization. Working Paper No. 64. Indaba Agricultural Policy Research Institute (IAPRI), Lusaka

Chavas JP, Holt T (1990) Acreage decisions under risk: the case of corn and soybeans. Am J Agric Econ 72:529-538

Chavas JP, Holt MT (1996) Economic behavior under uncertainty: a joint analysis of risk preferences and technology. Rev Econ Stat 78:329-335

Dorosh PA, Dradri S, Haggblade S (2009) Regional trade, government policy and food security. Food Policy 34:350-366

FEWS NET (Famine Early Warning System Network) (2014) Famine Early Warning Systems Network data center. www. fews.net/fews-data/335 (accessed 9 September 2019)

Fanzo J, McLaren R, Davis C, Choufani J (2017) Climate change and variability: What are the risks for nutrition, diets, and food systems? IFPRI Discussion Paper No. 01645. International Food Policy Research Institute, Washington, DC. http://ebrary.ifpri.org/cdm/ref/collection/p15738coll2/id/131228 (accessed 10 January 2018)

FAO (2016a) Zambia economic indicators. FAOSTAT. http: //faostat.fao.org/CountryProfiles/Country_Profile/Direct. aspx? lang=en\&area $=251$

FAO (2016b) The state of food and agriculture. Climate Change, Agriculture and Food Security, Rome. www.fao. org/publications/sofa/2016/en/ (accessed 10 January 2018)

Fezzi C, Bateman IJ (2011) Structural agricultural land use modelling for spatial agro-environmental policy analysis. Am J Agric Econ 93:1168-1188
Finkelshtain I, Chalfant JA (1991) Marketed surplus under risk: Do peasants agree with Sandmo? Am J Agric Econ 73:557-567

Govereh J, Jayne T, Mason N, Chapoto A (2006) Trends in agricultural and poverty indicators in Zambia. Policy Brief No. 2. Regional Strategic Analysis and Knowledge Support System for Southern Africa (ReSAKSS-SA), Pretoria

Govereh J, Jayne TS, Chapoto A (2008) Assessment of alternative maize trade and marketing policy interventions in Zambia. Working Paper No. 33. Food Security Research Project, Lusaka

Greene WH (2003) Econometric analysis, $5^{\text {th }}$ edn. Prentice Hall, Upper Saddle River, NJ

*Harrison GW, Humphrey SJ, Verschoor A (2010) Choice under uncertainty: evidence from Ethiopia, India and Uganda. Econ J (Lond) 120:80-104

Hempel S, Frieler K, Warszawski L, Schewe J, Piontek F (2013) A trend preserving bias correction - the ISI-MIP approach. Earth Syst Dyn Discuss 4:49-92

IPCC (2012) Managing the risks of extreme events and disasters to advance climate change adaptation. A special report of Working Groups I and II of the Intergovernmental Panel on Climate Change. Cambridge University Press, Cambridge

IPCC (2014) Climate change 2014: impacts, adaptation, and vulnerability. Part A: Global and sectoral aspects. Contribution of Working Group II to the Fifth Assessment Report of the Intergovernmental Panel on Climate Change. Cambridge University Press, Cambridge

IPCC (2018) Summary for policymakers. In: Masson-Delmotte V, Zhai P, Portner HO, Roberts D and others (eds) Global warming of $1.5^{\circ} \mathrm{C}$ : an IPCC special report on the impacts of global warming of $1.5^{\circ} \mathrm{C}$ above pre-industrial levels and related global greenhouse gas emission pathways. IPCC, Geneva, p 1-24

Jain S (2007) An empirical economic assessment of impacts of climate change on agriculture in Zambia. Policy Research Working Paper No. WPS 4291. World Bank, Washington, DC

Jarvis A, Lau C, Cook S, Wollenberg E, Hansen J, Bonilla O, Challinor A (2011) An integrated adaptation and mitigation framework for developing agricultural research: synergies and trade-offs. Exp Agric 47:185-203

Jayne TS, Govereh J, Chilonda P, Mason N, Chapoto A, Haantuba H (2007) Trends in agricultural and rural development indicators in Zambia. Working Paper No. 2. Regional Strategic Analysis and Knowledge Support System for Southern Africa (ReSAKSS-SA), Pretoria

Jones JW, Hoogenboom G, Porter CH, Boote KJ and others (2003) The DSSAT cropping system model. Eur J Agron 18:235-265

Just RE, Pope RD (1978) Stochastic specification of production functions and economic implications. J Econom 7:67-86

K Kalnay E, Kanamitsu M, Kistler R, Collins W and others (1996) The NCEP/NCAR 40-year reanalysis project. Bull Am Meteorol Soc 77:437-470

Krishnamurthy PK, Lewis K, Choularton RJ (2014) A methodological framework for rapidly assessing the impacts of climate risk on national-level food security through a vulnerability index. Glob Environ Change 25:121-132

Kumar N, Harris J, Rawatet R (2015) If they grow it, will they eat and grow? Evidence from Zambia on agricultural diversity and child undernutrition. J Dev Stud 51: 1060-1077

Livingston M, Roberts MJ, Rust J (2008) Optimal corn and soybean rotations. Paper presented at the AAEA annual meeting, Orlando, FL, 27-29 July 2008 
Lobell DB, Gourdji SM (2012) The influence of climate change on global crop productivity. Plant Physiol 160: 1686-1697

Kobell DB, Schlenker W, Costa-Roberts J (2011) Climate trends and global crop production since 1980. Science 333:616-620

Marenya P, Smith VH, Nkoyna E (2014) Relative preferences for soil conservation incentives among smallholder farmers: evidence from Malawi. Am J Agric Econ 96: $690-710$

* Mason MN, Jayne TS, Mofya-Mukuka R (2013) Zambia's input subsidy program. Agric Econ 44:613-628

Miller DJ, Plantinga AJ (1999) Modeling land use decisions with aggregate data. Am J Agric Econ 81:180-194

Moore MR, Negri DH (1992) A multicrop production model of irrigated agriculture, applied to water allocation policy of the Bureau of Reclamation. J Agric Resour Econ 17: 29-43

Mora C, Caldwell IR, Caldwell JM, Fisher MR, Genco BM, Running SW (2015) Suitable days for plant growth disappear under projected climate change: potential human and biotic vulnerability. PLOS Biol 13:e1002167

Müller C, Robertson RD (2014) Projecting future crop productivity for global economic modeling. Agric Econ 45:37-50

Mwala M, Gisselquist D (2012) Private-sector agricultural research and innovation in Zambia: overview, impact, and policy options. Agricultural Science and Technology Indicators, International Food Policy Research Institute. www.asti.cgiar.org/pdf/private-sector/Zambia-PS-Report. pdf

Myers SS, Zanobetti A, Kloog I, Huybers P and others (2014) Increasing $\mathrm{CO}_{2}$ threatens human nutrition. Nature 510: 139-142

Nelson A (2008) Global $1 \mathrm{~km}$ accessibility (CostDistance) model using publicly available data. World Bank, Washington, DC

Oude Lansink A, Peerlings J (1996) Farm-specific impacts of quantitative restrictions of N-fertiliser use in Dutch arable farming. J Agric Econ 52:38-52

* Piani C, Haerter JO, Coppola E (2010) Statistical bias correction for daily precipitation in regional climate models over Europe. Theor Appl Climatol 99:187-192

Pugh TAM, Müller C, Elliot J, Deryng D and others (2016) Climate analogues suggest limited potential for intensification of production on current croplands under climate change. Nat Commun 7:12608

Richardson KJ, Lewis KH, Krishnamurthy PK, Kent C, Wiltshire AJ, Hanlon HM (2018) Food security outcomes under a changing climate: impacts of mitigation and adaptation on vulnerability to food insecurity. Clim Change 147:327-341

Rosegrant MW, Koo J, Cenacchi N, Ringler C and others (2014) Food security in a world of natural resource scarcity: the role of agricultural technologies. International Food Policy Research Institute, Washington, DC

Rudolf B, Schneider U (2005) Calculation of gridded precipitation data for the global land-surface using in-situ gauge observations. In: Turk FJ, Bauer P (eds) Proc $2^{\text {nd }}$ Workshop Int Precipitation Working Group (IPWG), 25-28 October 2004, Monterey, CA. IPWG, Fort Collins, CO, p 231-247

Rudolf B, Hauschild H, Truth W, Schneider U (1994) Terrestrial precipitation analysis: operational method and required density of point measurements. In: Desbois M, Desalmond F (eds) Global precipitations and climate change. NATO ASI Series I, Vol 26. Springer-Verlag, Berlin, Heidelberg, p 173-186
Rudolf B, Fuchs T, Schneider U, Meyer-Christoffer A (2003) Introduction of the Global Precipitation Climatology Centre (GPCC). www.dwd.de/EN/ourservices/gpcc/gpcc.html

*Saha A (1993) Expo-power utility: a 'flexible' form for absolute and relative risk aversion. Am J Agric Econ 75: 905-913

Sandmo A (1971) On the theory of the competitive firm under price uncertainty. Am Econ Rev 61:65-73

* Schneider U, Becker A, Finger P, Meyer-Christoffer A, Rudolf B, Ziese M (2011) GPCC full data reanalysis version 6.0 (at $1.0^{\circ}$ ): monthly land-surface precipitation from rain-gauges built on GTS-based and historic data. doi: 10.5676/DWD_GPCC/FD_M_V6_100

Schneider U, Becker A, Finger P, Meyer-Christoffer A, Ziese M, Rudolf B (2014) GPCC's new land surface precipitation climatology based on quality-controlled in situ data and its role in quantifying the global water cycle. Theor Appl Climatol 115:15-40

Seshamani V (1998) The impact of market liberalization on food security in Zambia. Food Policy 23:539-551

Siegel PB, Alwang J (2005) Poverty reducing potential of smallholder agriculture in Zambia. Africa Region Working Paper Series No. 85. World Bank, Washington, DC

Sitko NJ, Chapoto A, Kabwe S, Tembo S and others (2011) Technical compendium: descriptive agricultural statistics and analysis for Zambia in support of the USAID mission's Feed the Future Strategic Review. Food Security Collaborative Working Paper No. 104016. Department of Agricultural, Food, and Resource Economics, Michigan State University, East Lansing, MI

*Tanaka Y, Munro A (2014) Regional variation in risk and time preferences: evidence from a large scale field experiment in rural Uganda. J Afr Econ 23:151-187

Tanaka T, Camerer CF, Nguyen Q (2010) Risk and time preferences: linking experimental and household survey data from Vietnam. Am Econ Rev 100:557-571

Theil H (1969) A multinomial extension of the linear logit model. Int Econ Rev 10:251-259

USDA (2015) National nutrient database for standard reference release 28. US Department of Agriculture, Agricultural Research Service. https://ndb.nal.usda.gov/ndb/ search

*Watanabe S, Hajima T, Sudo K, Nagashima T and others (2011) MIROC-ESM 2010: model description and basic results of CMIP5-20c3m experiments. Geosci Model Dev 4:845-872

WWeedon GP, Gomes S, Viterbo P, Shuttleworth WJ and others (2011) Creation of the WATCH forcing data and its use to assess global and regional reference crop evaporation over land during the twentieth century. J Hydrometeorol 12:823-848

Wiebe K, Lotze-Campen H, Sands R, Tabeau TA and others (2015) Climate change impacts on agriculture in 2050 under a range of plausible socioeconomic and emissions scenarios. Environ Res Lett 10:085010

World Bank (2010) World development report 2010: development and climate change. World Bank, Washington, DC. https://openknowledge.worldbank.org/handle/ 10986/4387

Wu J, Segerson K (1995) The impact of policies and land characteristics on potential groundwater pollution in Wisconsin. Am J Agric Econ 77:1033-1047

Zulu B, Jayne TS, Beaver M (2007) Smallholder household maize production and marketing behavior in Zambia: implications for policy. Food Security Collaborative Policy Briefs 54626, Michigan State University, East Lansing, MI

Submitted: February 4, 2019; Accepted: September 5, 2019 Proofs received from author(s): October 21, 2019 